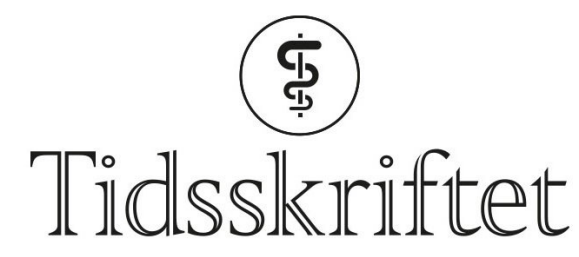

DEN NORSKE LEGEFORENING

\title{
Nyanser av grått
}

MINILEDER

ARE BREAN

Sjefredaktør

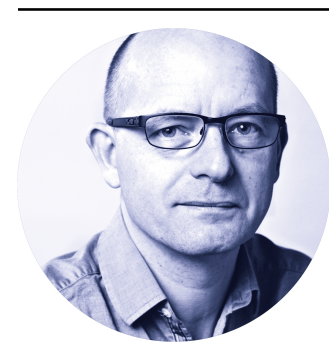

Halvparten av alle fastleger arbeider mer enn 50 timer i uken. Og regner man med legevakt, blir gjennomsnittsarbeidstiden 55,6 timer i uken. Det viser en nyere undersøkelse om fastlegers arbeidstid fra Nasjonalt kompetansesenter for legevaktmedisin.

Undersøkelsen har, ikke overraskende, falt Kommunenes Sentralforbund (KS) tungt for brystet. «Rapporten gir oss etter vår vurdering et noe unyansert bilde av legenes faktiske arbeidsbelastning», sa områdedirektøren for KS Arbeidsliv til Dagens Medisin.

Det har han helt rett i. Et så simpelt gjennomsnittstall bør åpenbart nyanseres: Undersøkelsen viser nemlig også at $10 \%$ av fastlegene arbeider mer enn 75 timer i uken og at $25 \%$ arbeider mer enn 62 timer. Og om KS trenger mer nyansering: Bare litt over $10 \%$ av fastlegene har en arbeidsuke lik eller kortere enn arbeidsmiljølovens maksgrense på 40 timer. Det er liten grunn til å foreta seg noe med dette, altså - med mindre man skulle være opptatt av rekrutteringen til en fastlegeordning $\mathrm{i}$ krise.

Publisert: 19. mars 2018. Tidsskr Nor Legeforen. DOI: 10.4045/tidsskr.18.06.01

(C) Tidsskrift for Den norske legeforening 2020. Lastet ned fra tidsskriftet.no 